\title{
Detached Pods for Studies of Phomopsis sojae Pods and Seed Colonization ${ }^{1}$
}

\author{
P. R. Hepperly and J. B. Sinclair ${ }^{2}$
}

\begin{abstract}
Pods with full-sized seed, which were green $\left(R_{6}\right)$ to brown $\left(R_{8}\right)$, were detached from greenhouse plants, surface-disinfected, and inoculated with Phomopsis sojae. After 1 week incubation at $95 \% \mathrm{RH}$ and $25^{\circ} \mathrm{C}$, woundinoculated Corsoy pods $\left(R_{6}\right)$ had increased frequencies of pod lesions and seed infection and reduced germination, in comparison with surface-inoculated pods. Stage of pod senescence was critical for rapid seed colonization. Low levels of seed infection were found in green Harosoy pods $\left(\mathbf{R}_{6}\right)$, whereas high levels were found in yellow $\left(R_{7}\right)$ and brown $\left(R_{8}\right)$ pods. Increasing period of pod incubation increased the rate of seed infection regardless of pod maturity. Lesions on green pods were centered about trichomes. Pubescent cultivars Corsoy, Hark and Harosoy developed more pod lesions than the sparsely pubescent Chippewa. Disease assessment of inoculated intact plants and inoculated detached pods for Hark, Rampage, Wells and Williams showed results from both methods were closely correlated, and cultivars Hark and Williams were less susceptible to Phomopsis sojae than Rampage and Wells.
\end{abstract}

\section{INTRODUCTION}

Phomopsis sojae Leh. causes pod and stem blight of soybean (12). Although the disease is named for symptom development on the pods and stems, disease damage is greatest on seed $(2-5,15,18,20)$. Diseased seeds are usually smaller, may be distorted and have reduced structural strength, less viability and poorer quality of oil and flour (5). Toxins from $P$. sojae can cause liver damage in chickens $(10,11)$. The purpose of these studies was to develop a $P$. sojae inoculation technique which could be used on a large scale in the laboratory.

\section{MATERIALS AND METHODS}

\section{ASSAY METHODS}

Pods were handharvested from greenhouse grown soybean plants. Pods contained full sized seed and were green $\left(R_{6}\right)$ to brown $\left(R_{8}\right)$. Harvested pods were surface-disinfected in $0.5 \% \mathrm{NaOCl}$ (10\% Clorox) for 4 minutes, placed on water saturated cellulose pods (Kimpac) and inoculated with $P$. sojae. Inoculum was prepared from 1-week-old cultures grown on potato-dextrose agar (PDA, Difco) and incubated at $25^{\circ} \mathrm{C}$. Culture plates $(9 \mathrm{~cm})$ were flooded with $15 \mathrm{ml}$ of sterile distilled water and mycelium

\footnotetext{
' Manuscript submitted to Editorial Board July 18, 1979.

${ }^{2}$ Assistant Professor and Professor, respectively, Department of Crop Protection, University of Puerto Rico, Mayagüez, and Department of Plant Pathology, University of Illinois, Urbana.
} 
was then scraped with a sterile cover slip. Suspended mycelium was then aseptically transferred to a sterile mortar and pestle and ground for 1 minute. A drop (0.07 to $0.08 \mathrm{ml}$ ) of the fungus suspension was then applied with a medicine dropper on the pod surface above developed seeds. Pods were incubated for 1 to 2 weeks at $95 \% \mathrm{RH}$ and $25^{\circ} \mathrm{C}$ in a seed germinator. Pod lesions (necrotic areas greater than $25 \mathrm{~mm}^{2}$ ) were counted and recorded. Pod tissues and seeds were separated, surfacedisinfected as previously described, and plated on sterile PDA. Recovery of $P$. sojae was recorded after 7 -day incubation at $25^{\circ} \mathrm{C}$.

In all experiments a randomized complete block design was used to minimize the influence of effects associated with incubator shelf levels on experimental error. Fifty pods were used for each replication and each treatment was replicated four times. Means were compared by Fischer's Least Significant Difference (FLSD).

\section{WOUNDING}

Green Corsoy pods with full sized beans $\left(R_{6}\right)$ were used for studying the effect of wounding on pod and seed colonization by P. sojae. Pods were 1) nontreated (control); 2) $P$. sojae inoculated but not wounded; or 3 ) wound inoculated with $P$. sojae. Pods were incubated 10 days and then assayed. Wounds were made by puncturing the surface of pods with a cluster of 5 insect dissecting pins (gauge 00).

\section{POD MATURITY AND INCUBATION PERIOD}

Harsoy pods with full sized beans were separated into groups of senescence based on pod color. Green $\left(\mathrm{R}_{6}\right)$, yellow $\left(\mathrm{R}_{7}\right)$ and brown $\left(\mathrm{R}_{8}\right)$ pods were either nontreated (control) or $P$. sojae inoculated without wounding (treated). Pods were incubated for 4, 6, 8, and 10 days, and then seeds and pods were assayed for recovery of $P$. sojae.

\section{POD PUBESCENCE}

Green pods with full sized beans $\left(\mathrm{R}_{6}\right)$ of the pubescent cultivars Corsoy, Hark, and Harosoy and the sparsely pubescent cultivar Chippewa were used for studying the effects of trichome density on pod lesion development. All pods were examined visually and under the microscope after 1 , 2, 4 and 10 days. At 10 days, pod lesions were recorded and isolations from pods and seed were made.

\section{COMPARATIVE ASSAY}

Eight plants each of the cultivars, Hark, Rampage, Wells and Williams were grown to physiological maturity $\left(\mathrm{R}_{6}\right)$ in a growth chamber programmed for 12 hours of light $\left(700 \mu \mathrm{Ein} / \mathrm{m} / \mathrm{sec}\right.$ intensity) with $28^{\circ} \mathrm{C}$ to $23^{\circ} \mathrm{C}$ day-night temperatures and relative humidity of $60 \%$. Pods from 
four of the plants were detached for assay and incubated in a moist chamber for 2 weeks after inoculation with $P$. sojae. The remaining plants were sprayed with a suspension of $P$. sojae spores. Inoculum was prepared by flooding sporulating cultures of $P$. sojae grown on oatmeal agar (Difco), collecting suspended alpha conidia and adjusting their concentration to $10^{5}$ per $\mathrm{ml}$. Inoculum was atomized over plants and plants were incubated under a greenhouse mist bench delivering 1-minute mist in four 15-second increments every hour. Plant symptoms were rated on percentage of plant surface covered wit pycnidia (16) after 24 days delayed harvest. After rating was done, isolations were made for the seeds of each plant.

\section{RESULTS}

Increased disease severity was found on yellow Harsoy pod $\left(\mathrm{R}_{7}\right)$ compared to that on green pods of the same cultivar (fig. 1). Visible lesions, $P$. sojae recovery and germination of seed were 5,8 , and $91 \%$, respectively,

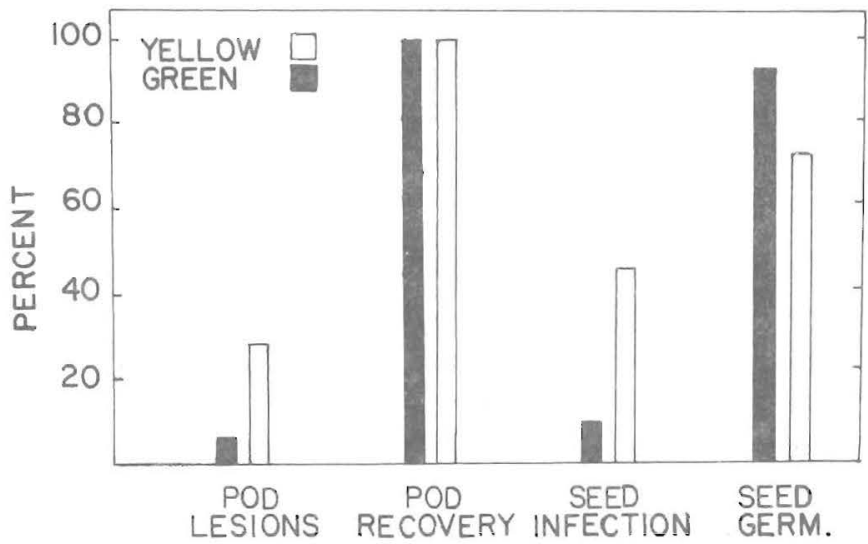

FIG. 1.-The relative development of pod and stem blight on inoculated green and yellow pods containing full-sized Harosoy soybean seed. Values based on 4 replications of 50 pods each.

for green pods inoculated with $P$. sojae, and 26,45 , and $73 \%$, respectively, for yellow pods. All pods, regardless of color, were infected by P. sojae.

Extending the incubation period of inoculated green and brown Harosoy pods increased $P$. sojae recovery of seed, and decreased germination (fig. $2 \mathrm{~A}$ and $\mathrm{B}$ ). In green pods the first seedborne infection was detected after 6 days, with 30\% incidence occurring at 10 days. Germination of seed from inoculated green pods was $92 \%$ prior to incubation and $79 \%$ after 10 days' incubation. Phomopsis sojae was detected in $34 \%$ of seed from inoculated brown pods after 4 days, and in $88 \%$ after 10 days. 
Germination of seed from noninoculated brown pods was $95 \%$ with no incubation and $28 \%$ after 10 days' incubation.

When green pods with full sized beans (in Corsoy) were wound- or surface-inoculated or noninoculated, the following was found: seed germination and $P$. sojae recovery from seed were 13 and $91 \%$, respectively; when pods were wound-inoculated, 65 and $51 \%$, respectively; when pods were surface-inoculated, 89 and $2 \%$, respectively; when pods were nonin-
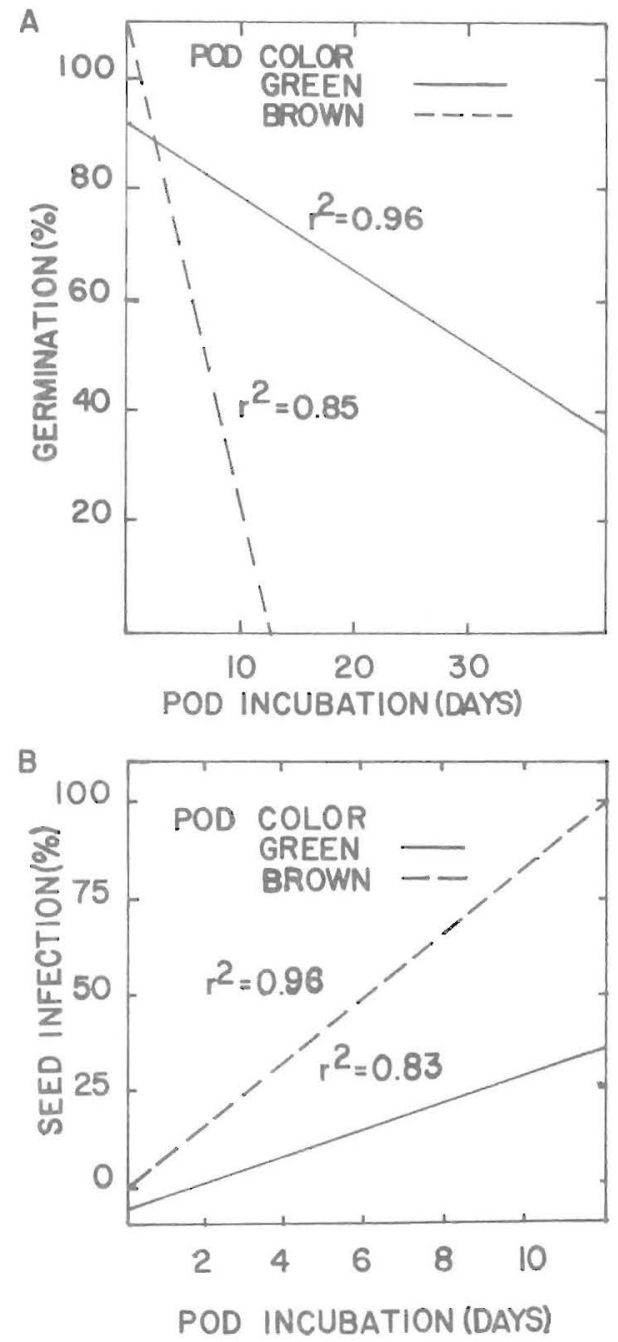

FIG. 2.-Linear regression lines which relate time after $P$. sojae pod inoculation to A) seed germination and B) P. sojae seed infection. Lines are based on 4 replications of 50 Harosoy pods for each pod color at each incubation period (4, 5, 8, and 10 days). 
oculated (fig. 3). A highly significant positive correlation $(r=0.94)$ was found between percentage pod lesions and $P$. sojae recovery brown seed. Highly significant negative correlation between seed germination and $P$. sojae recovery or pod lesions were $r=0.94$ and -0.99 , respectively.

Hyphal penetration of the soybean pod tissue occurred through wounds or through the intercellular spaces between trichomes and surrounding

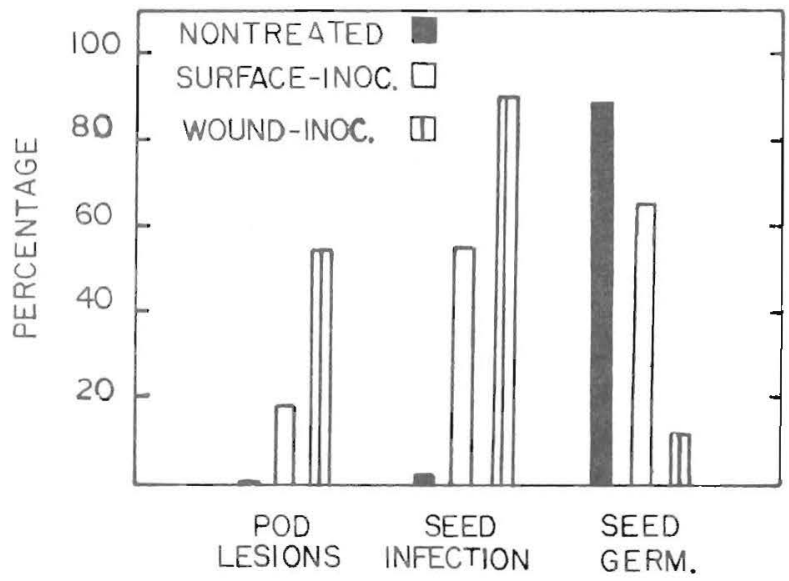

FrG. 3.-The relative development of pod and stem blight on noninoculated, inoculated, and inoculated and wounded green pods containing full-sized Corsoy soybean seed. Values based on 4 replications of 50 pods each.

TABLE 1.-The relationship of soybean pod pubescence to pod and stem blight development in detached pods of four soybean cultivars inoculated with $\mathrm{P}$. sojae

\begin{tabular}{lcccc}
\hline \multicolumn{1}{c}{ Cultivar } & Pod pubescence & P. sojae from seed & Germination & Pod lesions \\
\hline & & $\%$ & $\%$ & $\%$ \\
Chippewa & $\mathrm{SP}^{\prime}$ & $30 \mathrm{a}^{2}$ & $83 \mathrm{a}$ & $15 \mathrm{a}$ \\
Hark & $\mathrm{P}$ & $38 \mathrm{a}$ & $78 \mathrm{a}$ & $19 \mathrm{a}$ \\
Harosoy & $\mathrm{P}$ & $50 \mathrm{~b}$ & $63 \mathrm{~b}$ & $44 \mathrm{~b}$ \\
Corsoy & $\mathrm{P}$ & $65 \mathrm{~b}$ & $50 \mathrm{c}$ & $52 \mathrm{~b}$ \\
\hline
\end{tabular}

${ }^{1} \mathrm{SP}=$ Slightly pubescent and $\mathrm{P}=$ pubescent.

${ }^{2}$ Means are based on four replications of 50 pods. Means followed by the same letter do not differ statistically at $\mathrm{P}=0.05$ using FLSD.

epidermal cells. Penetration was never observed between epidermal cells other than that surrounding trichomes. On $P$. sojae inoculated green pods, lesions ( $1 \mathrm{~mm}$ in diameter) developed around trichomes after 24 to 48 hours. Chippewa, the slightly pubescent cultivar, developed fewer pod lesions (15\%) than the pubescent ones of Corsoy (52\%), Hark (29\%), or Harosoy (44\%) (table 1).

Disease severity measurements on either inoculated intact plants or detached pods showed Hark and William were less susceptible to P. sojae than Rampage and Wells (table 2). 
TABLE 2.-Disease reactions of detached pods and intact plants from four soybean cultivars inoculated with P. sojae

\begin{tabular}{lcccccccc}
\hline \multirow{2}{*}{ Cultivar } & \multicolumn{3}{c}{ Detached pods $^{1}$} & & \multicolumn{3}{c}{ Intact plants $^{2}$} \\
\cline { 2 - 3 } \cline { 7 - 8 } & Pod lesions & $\begin{array}{c}\text { Seedborne } \\
\text { P. sojae }\end{array}$ & Germination & & $\begin{array}{c}\text { Disease } \\
\text { rating }\end{array}$ & $\begin{array}{c}\text { Seedborne } \\
\text { P. sojae }\end{array}$ & Germination \\
\hline Wells & $63 \mathrm{a}^{4}$ & $100 \mathrm{a}$ & $12 \mathrm{a}$ & & $4.9 \mathrm{a}$ & $100 \mathrm{a}$ & $6 \mathrm{a}$ \\
Rampage & $50 \mathrm{ab}$ & $76 \mathrm{~b}$ & $40 \mathrm{~b}$ & & $4.7 \mathrm{a}$ & $86 \mathrm{~b}$ & $21 \mathrm{~b}$ \\
Hark & $25 \mathrm{bc}$ & $59 \mathrm{bc}$ & $76 \mathrm{~cd}$ & & $4.3 \mathrm{~b}$ & & $53 \mathrm{c}$ & $69 \mathrm{c}$ \\
Williams & $15 \mathrm{c}$ & $22 \mathrm{~d}$ & $83 \mathrm{~d}$ & & $3.0 \mathrm{c}$ & $20 \mathrm{~d}$ & $85 \mathrm{~d}$ \\
\hline
\end{tabular}

${ }^{1}$ Pods were surface-inoculated with a mycelium suspension of $P$. sojae and incubated 10 days at $96 \% \mathrm{RH}$ and $25^{\circ} \mathrm{C}$.

${ }^{2}$ Based on four plants inoculated with an alpha conidia suspension $\left(10^{5} / \mathrm{ml}\right)$ and delay harvested by 30 days.

${ }^{3}$ Assessment based on the percentage of plant surface area covered by pycnidia; $0=$ no visible pycnidia; $I=$ pycnidia over $20 \%$ of surface; $2=$ pycnidia over $40 \%$ of surface; $3=$ pycnidia over $60 \%$ of surface; $4=$ pycnidia over $80 \%$ of surface; and $5=$ pycnidia over all surface (15).

${ }^{4}$ Values followed by the same letter do not differ statistically at $\mathrm{P}=0.05$ and $\mathrm{P}=0.01$ levels, respectively, using FLSD.

\section{DISCUSSION}

Studies of $P$. sojae on soybean have led to conflicting reports on the parasitic ability of this fungus. When the ability of this fungus to induce visible symptoms on inoculated greenhouse plants was used to determine its pathogenicity, workers concluded $P$. sojae had little or no parasitic ability and was classified as a rapid colonizer of soybean debris $(1,6,13)$. Isolations from surface-disinfected soybean tissue have shown $P$. sojae is present throughout the soybean life cycle $(7,8,9,14)$.

It is not known when $P$. sojae infects seeds. Compared to seed from inoculated green pods, seed from inoculated yellow pods had dramatic increases in seed infection. Increased disease development at this point may be related to breakdown of mechanisms governing latency of infection. In bananas, yellowing is associated with soluble sugar and amino acid increase and breakdown of physiological resistance to fruit rotting fungi $(17,19)$. It appears that an analogous situation develops in soybean. Delayed harvest increases infection by $P$. sojae (21). Under normal harvest, seed quality will be dependent on environmental condition during and after the yellowing of pods.

There is little information on the effect of pod wounds on pod and seed colonization by $P$. sojae. Whether wounded or not, inoculated pods were infected. Wounding, however, increased severity of pod symptoms and the numbers of symptomatic and infected seed.

Two probable explanations for the latency of infections are lack of soluble substrates and presence of fungistatic metabolites (19). These conditions are probably altered by wounding tissue.

Our observations suggest that trichomes may serve as major penetra- 
tion sites for $P$. sojae. The role of wounds as prerequisites for entry may be of less importance than previously thought. More work comparing disease reaction of glabrous and pubescent isolines is suggested.

Using detached pods instead of intact plants for inoculation saves time, labor and space. The method could be useful in screening for soybean line reaction, fungicide efficacy, and for presence of races of the pathogen.

\section{RESUMEN}

Inoculando vainas desprendidas de la planta, se desarrolló un método para evaluar el grado de susceptibilidad de cultivares de soya [Glycine max (L.) Merr.] a la infección por Phomopsis sojae. Se encontró que el grado de maduración de la vaina determina el grado del daño causado por este hongo en la semilla. Semillas de vainas amarillas o marrón claro mostraron una germinación baja y una tasa mayor de infección por $P$. sojae que las de vainas verdes. Los síntomas en las vainas verdes y la infección en las semillas provenientes de éstas aumenta cuando las vainas se hieren antes de aplicar el inóculo. Cuando se inocula sin heridas, los síntomas y la infección se encuentran localizados en la región alrededor de la base de los tricomas de las vainas, pero no en otras células epidérmicas. La susceptibilidad de las cultivares Corsoy, Hark, Wells y Williams es igual, independientemente de si se evalúan plantas enteras inoculadas o vainas inoculadas.

\section{LITERATURE CITED}

1. Athow, K. L., and Caldwell, R. M., 1954. A comparative study of Diaporthe stem canker and pod and stem blight of soybean, Phytopathology 44: 319-25.

2. Atlas de Gotuzzo, E., 1970. Microorganisms isolated from normal and spotted soybean seed; their effect on percentage germination, Rev. Fac. Agron. Vet. Univ. Buenos Aires 18: 7-16.

3. Bolkan, H. A., de Silva, A. R., and Cupertino, F. P., 1976. Fungi associated with soybean and bean seeds and their control in central Brazil, Plant Dis. Rep. 60: 545-48.

4. Ellis, M. A., Machado, C. C., Prasartsee, C., and Sinclair, J. B., 1974. Occurrence of Diaporthe phaseolorum var. sojae (Phomopsis sp.) in various seedlots, Plant Dis. Rep. 58: 173-6.

5. Hepperly, P. R., and Sinclair, J. B. 1978. Quality losses in Phomopsis sojae infected soybean seed, Phytopathology 68: 1684-7.

6. Hildebrand, A. A., 1956. Observations on stem canker and pod and stem blight of soybeans in Ontario, Can. J. Bot. 34:577-99.

7. Kilpatrick, R. A., and Johnson, H. W., 1953. Fungi isolated from suybean plants at Stoneville, Mississippi in 1951-1952. Plant Dis. Rep. 37:98-100.

8. Kmetz, K., Ellet, C. W., and Schmitthenner, A. F., 1974. Isolation of seedborne Diaporthe phaseolorum and Phomopsis from immature soybean plants, Plant Dis. Rep. 58:978-82.

9. - - Schmitthenner, A. F., and Ellett, C. W., 1978. Soybean seed decay: prevalence of infection and symptom expression caused by Phomopsis sp., Diaporthe phaseolorum var. sojae, and D. phaseolorum var. caulivora. Phytopathology 68:836-40.

10. Kung, H. C., Chipley, J. R., Latshaw, J. D., Kerr, K. M., and Wilson, R. F., 1977. 
Chronic mycotoxicosis in chicks caused by toxins from Phomopsis grown on soybean, J. Comp. Pathol. 87:325-33.

11. _- Chipley, J. R., and Latshaw, J. D., 1977. Investigations into hepatotoxins in moldy soybeans, Poult. Sci. 54:1784.

12. Lehman, S. G., 1923. Pod and stem blight of soybean, Ann. M. Bot. Gard. 10:119-69.

13. Luttrell, E. S., 1947. Diaporthe phaseolorum var, sojae on crop plants, Phytopathology $37: 445-65$.

14. Pastor-Corrales, M. A. and Lyda, S. D., 1978. Time of infection of Glycine max by Diaporthe phaseolorum var. sojae. Proc. Am. Phytopathol. Soc. 4:227 (Abstr.)

15. Peterson, J. L., and Strelecki, R. F., 1975. The effect of Diaporthe phaseolorum n soybeam germination and growth in New Jersey. Plant Dis. Rep. 58:130-3.

16. Prasartsee, C., Tenne, F. D., Ilyas, M. B., Ellis, M. A., and Sinclair, J. B., 1975. Reductions of internally seedborne Diaporthe phaseolorum var. sojae by fungicide sprays. Plant Dis. Rep. 59:20-3.

17. Simmonds, J. H., 1963. Studies in the latent phase of Colletotrichum species, concerning ripe rots of tropical fruits. Queensl. J. Agri. Sci. 20:373-424.

18. Strelecki, R. F., 1963. The effect of Diaporthe phaseolorum varieties sojae and cauli. vora on soybean seed germination and growth in New Jersey, Master's Thesis, Rutgers Univ., N.J. 44 pp.

19. Verhoeff, K., 1974. Latent infections by fungi, Ann. Rev. Phytopath. 12:99-110.

20. Wallen, V. R., and Seaman, W. L., 1963. Seed infection of soybean by Diaporthe phaseolorum and its influence on host development, Can. J. Bot. 41:13-1.

21. Wilcox, J. R., Laviolette, F. A., and Athow, K. L., 1974. Deterioration of soybean seed quality associated with delayed harvest, Plant Dis. Rep. 58:130-132. 